S. I. Cheberiachko, orcid.org/0000-0003-3281-7157, L. S. Koriashkina, orcid.org/0000-0001-6423-092X, O.V. Deryugin, orcid.org/0000-0002-2456-7664, M. M. Odnovol, orcid.org/0000-0002-2022-7996
Dnipro University of Technology, Dnipro, Ukraine, e-mail: koriashkina.1.s@nmu.one

\title{
RATIONAL ORGANIZATION OF THE WORK OF AN ELECTRIC VEHICLE MAINTENANCE STATION
}

Purpose. Improvement of efficiency of organizing the work of an electric vehicle (EV) service station (SS) due to the rational distribution of its resources.

Methodology. System analysis of technological processes of diagnosing EVs depending on customer needs; mathematical modeling, operations research, combinatorial optimization.

Findings. An analysis of technological processes of diagnosing EVs is carried out. The information about the basic services provided by the electric vehicle service station is collected and systemized. For each of them it is established what processes constitute the service, their resources, how many of them operate and the duration of each operation. Mathematical models are built to organize the operation of an EV SS, which allow ensuring a uniform load of available resources and determining the time for the next service. A model problem to reserve resources to serve the largest number of clients is resolved. The proposed mathematical model is generic so that it can be used by any service enterprise that seeks to rationally distribute its resources while providing services to a large number of customers.

Originality. It has been found that the efficiency of a service station is increased by reducing the downtime of equipment or human resources, as well as by serving the largest number of customers who contacted a service company.

Practical value. A mathematical model is proposed that will allow, first, tracking the employment of resources; second, increasing the throughput by the rational usage of resources.

Keywords: electric vehicle, service station, diagnosis process, combinatorial optimization

Introduction. Developing conventional and environmentally-friendly vehicles is an actual trend in the world. In sales, every year such well-known automotive concerns as "Tesla", "Nissan", "Hyundai", "Mercedes Benz", "BMW", "Renault", "BYD", and many others present their latest high-tech concept-development of electric vehicles (EV). The article [1] contains a comprehensive overview of research and development related to the usage of electric vehicle technology. The work [2] aims to raise consumer awareness of the benefits of the electric drive and the importance of the transition to it.

The production of energy-efficient and environmentallyfriendly vehicles is currently developing intensively due to society's demand for environmental protection.

Each car has a certain operating and maintenance period, which is accompanied by the depreciation of relevant mechanisms, units, systems and components. It leads to the development and expansion of the network of service infrastructure service stations for electric vehicles [3]. Such stations not only determine the technical status of the EV, its compliance with the requirements of the legislation governing the trouble-free, and safe operation but also identify and predict the performance of electric cars and take measures to prevent possible failures. In addition, it will contribute to road traffic safety, because according to [4] the percentage of road accidents due to technical failure reaches $1 \%$.

Note that the service station must provide high-quality and timely service at a competitive price. It implies their owners should organize their work effectively through the rational loading of production equipment and other material and human resources. Therefore, it is important to solve optimization problems to increase the productivity of the resources' usage of diagnostic and repair sites and get the maximum profit out of this activity.

Literature review. A lot of research in the scientific literature is devoted to the development of road transport infra-

(C) Cheberiachko S. I., Koriashkina L. S., Deryugin O. V., Odnovol M. M., 2020 structure. Rational usage of existing transport networks, implementation of the advantages of their geographical location and communication capacity to ensure timely and high-quality delivery of goods are an indicator of the integration of the transport system [5]. The works [6,7] explain the productivity of vehicles. In [6], for example, the authors substantiate the possibility of reducing the time of moving machines during the transportation of rock mass by changing the structure of the slopes of road sections. And in [7], the design parameters of the transmission are determined, taking into account the minimization of fuel consumption so that to get the maximum efficiency.

A significant amount of scientific work is devoted to the development of EV service systems. In particular, [8] presents an overview and classification of methods of intelligent charging of electric vehicles for fleet operators. In [9], the authors suggest a four-stage optimization and control algorithm for a two-way charging station for an electric vehicle, which is equipped with photoelectric generation and a fixed energy battery and integrated into a commercial building. This algorithm aims to minimize operating costs associated with meeting customer needs, taking into account potential uncertainties, as well as real-time balancing supply and demand by adjusting the optimally planned charge/discharge of the mobile battery.

The authors of [10] note that when penetrating the electric vehicle market, many companies consider the integration of electric vehicles into their fleet. The reason is that electric vehicles do not have local greenhouse gas emissions; they produce minimal noise; they do not depend on fluctuations in oil prices. But the well-studied problem of vehicle routing (VRP) extends to the problem of electric vehicle routing (E-VRP), which takes into account the specific characteristics of electric vehicles. This article describes several options for E-VRP and related issues and suggests options for overcoming them.

The task of developing an integrated production space, in which it would be possible to introduce the basic provisions of production logistics and reduce the economic losses of car service, is urgent [11]. 
Much attention is paid to the development of remote services (software) that can detect car breakdowns at a distance [12] and reduce the load on car mechanics [13] by mapping the flow of various processes in car systems and modeling their flow under different environmental influences [14]. For example, the technical support system "SBDSS" allows formulating solutions for the necessary diagnosis and repair of worn parts or units of the car. This reduces both the queue and customer service time. Another direction is drawing up non-standard work schedules: at weekends, after the main work [15]. Of course, this approach is not a complete solution to the problem but only allows you to respond situationally to the tasks. A number of production-technological and organizationalmanagerial problems of car service in the conditions of the uneven flow of applications for repair are considered in the monograph [16].

Note that in practice, various approaches are applied to design the solution of service, organizational, and social problems of car service for economical usage of balance and labor resources. The most common methods are system and data analysis to assess the demand for services, development, and selection of projects and technological stages of service cycles by studying and assessing customer needs, and so on. [17]. Much of the work concerns either the optimal location of charging stations for EM, such as [18]; or reducing the costs associated with the operation of cars by determining and using the optimal number of posts for current repairs of EV. Mathematical models of such problems are combinatorial by nature and can be classified as operations research problems, or more precisely, scheduling theory (ST). In general, ST explores the tasks where it is necessary to streamline or determine the sequence of a set of works, usage of any means, and others. In TR tasks, it is necessary to determine when and in what sequence to perform tasks. The search for the optimal or close to the optimal schedule is carried out using one of four approaches: mathematical programming, combinatorial, heuristic, and probabilistic ones [19]. The paper [20] provides a detailed review of recent publications on problems in the scheduling theory, where the work is systematized by methods for solving problems and by the industry as an area of their practical application.

The main difficulty of the problems of the scheduling theory is the fact that in their mathematical formulations, several conditions must be met alternatively: either one operation is started earlier, or another. It complicates both the process of constructing the mathematical models themselves and the application of linear programming methods to solve them because the time of solving the problem using such approaches is exponential. There are various widely used techniques based on the branches and borders method or the method of implicit search. The combinatorial approach is reduced to a purposeful permutation of pairs of works of some initial sequence until the optimal (or close to optimal) solution is obtained.

Approximate methods for solving ST problems allow obtaining acceptable solutions at a relatively low cost of time and resources. Conditionally approximate methods are divided into heuristic and probabilistic. Heuristic algorithms are based on the so-called reducing requirements method, which implies refusing to find the optimal solution in a reasonable time. Heuristic algorithms use various reasonable considerations without strict justifications. The local search method is also widely used. In this method, a pre-selected set of permutations is considered to consistently improve the initial solution as long as such improvement is possible; otherwise, the local optimum is reached. To solve the problem of mixed-integer linear programming, which is a mathematical model of one class of the scheduling theory problems, a combined method based on the usage of several known heuristics is often proposed. Although all these methods are convenient for their implementation on a PC, even when solving cumbersome problems, their significant disadvantage is the difficulty of assessing the proximity of the obtained schedules to the optimal.
Purpose. Fierce competition in the market of EV services makes us search for new forms of organization of activities and ways to attract and retain customers.

Therefore, the purpose of the research is to increase the efficiency of the EV service station by the optimal reservation of the service time of applications (according to certain criteria), as well as the rational allocation of material and technical resources.

The object of the research is an electric car service station.

The subject of research is mathematical models of problems of optimal resource reservation during the scheduling of the electric car service station.

To achieve this goal, we need to solve the following tasks:

- to analyze the situational technological processes of diagnosing an EV using the system approach;

- to build a mathematical model of the problem of optimal reservation of service time of the application (according to certain criteria) with a rational distribution of material and technical resources of the station with simultaneous diagnostics of several EVs;

- to demonstrate the feasibility of using the proposed approach to the scheduling of the service station on the example of solving the model problem of optimal reservation of service time of the application.

Methods. We consider the problem of optimizing the schedule of the electric car service station in the next statement. Let the electric vehicle service station have several sections for EV diagnosing and employ several craftsmen, mechanics and other staff. It provides numerous services using different types of equipment. Each of the resources has its own current weekly (or even monthly) schedule.

Assume that when a new request for EV service is received, we know what resources and during what time should be used to meet all needs of a client's.

It is necessary to find the most beneficial service term for any new request received. That is to reserve the most suitable time of service provision. The objective for the optimal service time reservation may be different. For example, we can find the nearest possible operating period or request minimizing downtime of a certain resource. We will consider these two criteria during the mathematical description of the schedule and redundancy optimization problem.

We will form the weekly resource schedule by a binary array, the dimension of which equals to the number of time blocks of a resource (Fig. 1). Such a resource timetable representation is the most intuitive data structure. It is convenient for recording mathematical models of optimization problems that arise in practice.

Thus, we will consider the weekly schedules of all resources as separate objects. As a minimum unit, we take a minute. We will operate with time blocks - logical units of time. The time block for a resource contains $\mathrm{X}$ minutes and we will presume that it is the same for all resources.

In the problem, we need to choose open time intervals of size $\mathrm{h}$ (duration of service) for reserving ordered by priority, so that the highest priority will correspond to the time interval, which, being reserved, will improve the schedule in terms of a specific objective function. The above two optimality criteria can be reformulated as follows:

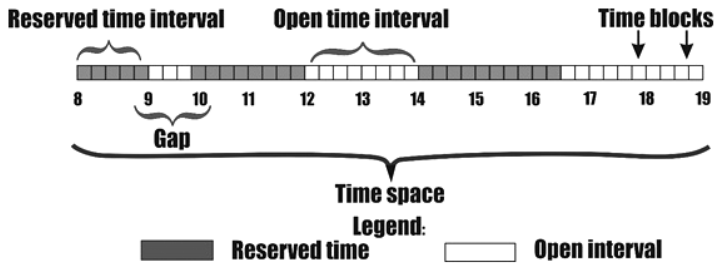

Fig. 1. Representation of the resource schedule (for car mechanic, equipment, etc.) 
- it is necessary to find the date and time of the first synchronous open time interval for all resources of different types that should be used for the earliest possible provision of a new service for diagnosing an electric vehicle;

- to minimize gaps in the schedule of a certain resource (or all resources) when reserving time to provide a new EV diagnosing service.

Both problems can be solved by the exhaustion of open time intervals of all resources which provide EV diagnosing. However, as the number of needed resources increases, such a going-through search will slow down. Therefore, there is a need to improve the search algorithm by either optimizing the schedule data representation (for example, by indexing this data) or optimizing the search strategy. It is also possible to apply both approaches.

Let $N$ be the number of resources, among which $D_{p}$ is the number of resources of the $p^{\text {th }}$ type; $n$ is the number of time blocks in the weekly schedule. Assume, for example, that a time block equals 10 minutes.

We present current schedule of the $i^{\text {th }}$ resource of the $p^{\text {th }}$ type in the next vector

$$
R_{i}^{p}: R_{i}^{p}=\left\{r_{i j}^{p}\right\}, \quad p=1, \ldots, N ; i=1, \ldots, D_{p} ; j=1, \ldots, n,
$$

where

$$
r_{i j}^{p}= \begin{cases}0- & \text { if } j^{\text {th }} \text { time block is open } \\ 1, & \text { otherwise }\end{cases}
$$

We enter the parameters of the service (request) that should be provided.

We will consider that there can be more than 1 inquiry, $k$ is the serial number of a request.

Let vector $A_{k}$ to be a set of resources involved in providing the service

$$
A_{k}=\left\{a_{k p}\right\}, \quad p=1, \ldots, N, 0<a_{k p} \leq D_{p},
$$

where $a_{k p}$ is the number of resources of the $p^{\text {th }}$ type which is required to provide the service.

Interval $\left[l_{k}, m_{k}\right]$ determines a time span, during which (if possible) the service should be performed: $1 \leq l_{k}<m_{k} \leq n ; h_{k}-$ service duration in time blocks.

Let us calculate the value $G_{k}$ - the number of all possible combinations of all types of resources that can provide the service $A_{k}$

$$
G_{k}=\prod_{p: a_{k p}>0} C_{D_{p}}^{a_{k p}} .
$$

For each resource group $q_{k}=1, \ldots, G_{k}$, we introduce the vector $T^{q}$ of resources employment in the group $q$ to provide diagnostic service according to the relevant regulations $A_{k}$

$$
T^{q k}=\left\{t_{i}^{q k p}\right\}, \quad p=1, \ldots, N ; i=1, \ldots, D_{p} ; q=1, \ldots, G_{k},
$$

where

$$
t_{i}^{q k p}=\left\{\begin{array}{ll}
1 & \text { if } i^{\text {th }} \text { resource of } p^{\text {th }} \text { type takes part } \\
\text { in the group with number } q_{k}
\end{array} .\right.
$$

Obviously

$$
\begin{gathered}
T^{q k}: \sum_{i=1}^{D_{p}} t_{i}^{q k p}=a_{k p} \text { for each } p \text { and } q_{k} ; \\
T^{q k}=\left\{t_{i}^{q k p}\right\}, \quad p=1, \ldots, N ; i=1, \ldots, D_{p} ; q=1, \ldots, G_{k} .
\end{gathered}
$$

For each resource selection option $T^{q k}$, we compose a vector

$$
S^{q k}=\bigcup_{p, i: t_{i}^{q k}=1} R_{i}^{p}
$$

elements of which are determines in the next way

$$
i_{j}^{q k}=\left\{\begin{array}{l}
0-\text { if } j^{\text {th }} \text { time block of the "team" } q_{k} \text { is open } \\
1, \quad \text { otherwise }
\end{array}\right.
$$

In fact, $S^{q k}$ is a weekly schedule of the resources group $T^{q k}$.

For $q_{k}=1, \ldots, G_{k}$ we find an array $f^{q k}=\left(f_{1}^{q k}, f_{2}^{q k}, \ldots, f_{s}^{q k}\right)$, elements of which correspond to numbers of time blocks for starting service $A_{k}$ by resources group $T^{q k}$

$$
l_{k} \leq f_{r}^{q k} \leq m_{k}: s_{f_{r}^{q k}}^{q k}+s_{f_{r}^{q k}+1}^{q k}+\ldots+s_{f_{r}^{q k}+h_{k}-1}^{q k}=0, r=1, \ldots, s .
$$

Then the problem of finding the closest possible time spans for service of $K$ clients will be written in the following way:

Problem 1. For each $k^{\text {th }}$ request, $k=1, \ldots, K$, (sequentially) it is necessary to find the first element of array $f^{q k}$ closest to the time foreseen as the beginning of the service $l_{k}$

$$
f_{*}^{k} \rightarrow \min _{q k} \min _{r} f_{r}^{q k} .
$$

If $\left(f^{q k}\right)^{*}$ is vector $f^{q k}$, sorted in ascending order of total gap size. Let us use $w^{p, i}$ to denote the total size of the gaps in the schedule of the $i^{\text {th }}$ resource of the $p^{\text {th }}$ type and $w_{f_{r}^{q k}}^{p, i}-$ for the total size of the windows in the schedule of the $i^{\text {th }}$ resource of the $p^{\text {th }}$ type after reserving (closing) it into the time interval with the size $h_{k}$ beginning from $f_{r}^{q k}$. For each $f_{r}^{q k}$, which will be found in problem 1 , the value

$$
\Delta_{r}^{q k}=\sum_{p, i: t_{i}^{q k p}=1} w_{f_{r}^{q k}}^{p, i},
$$

can be calculated. After this operation, we can formulate the problem of minimizing total gaps in the resources schedule.

Problem 2. For each $k^{\text {th }}$ request, $k=1, \ldots, K$, (sequentially) to find

$$
\Delta_{*}^{k} \rightarrow \min _{q k} \min _{r} \Delta_{r}^{q k} .
$$

Note 1. During computer implementation, the value $G_{k}$ can be reduced, taking into account among all resources only those that have an open interval $h_{k}$ (at least one) in their schedule during the period $\left[l_{k}, m_{k}\right]$.

Note 2 . For some $q$ the array $f^{q}$ may be empty, which means that it is impossible to perform a diagnostic service $A$ by resource group $T^{q}$

Note 3. In problem 2, the criterion may be the total number of gaps instead of the total size of the gaps for any resource or for all resources, as described here.

So, solving problems 1 and 2 can increase the efficiency of the EV service station by reducing the downtime of equipment or human resources, as well as meeting the needs of as many customers as possible to the service company.

Note that the presented model is constructive since it reproduces the very process of its solution. The constructed problem is a combinatorial optimization problem. If the dimension of the task is small (which corresponds to the situation in practice for specific service areas), the problem can be easily solved by going through and sorting the allowable sets of resources that can provide a particular service at a given time.

Application of EV owners to the service station to obtain services for diagnosing EV is caused by the following needs:

- the need to pass a mandatory inspection;

- the need to assess the technical condition of the EV in case of purchase or sale of a vehicle;

- investigation of sudden failure of components, systems, units of the EV.

The most common services involving high-tech diagnostic equipment provided by modern EV service stations include diagnosing elements of the chassis, brake system, backlash steering system, outdoor lighting system, as well as computer diagnostics of basic units, assemblies, equipment, EV systems (Fig. 2). 


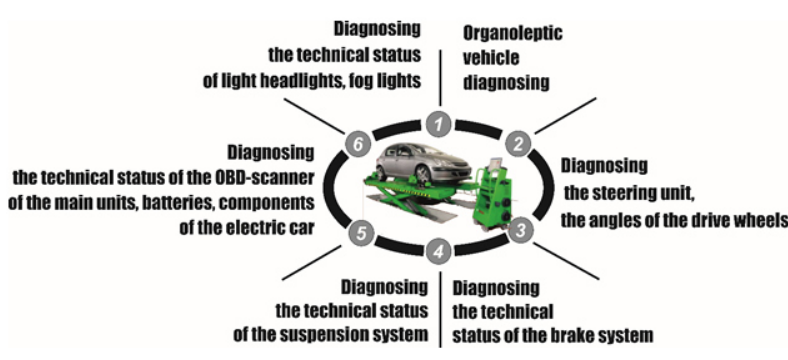

Fig. 2. Technological diagnostics operations provided at EV Service stations depending on the client's requirements

For example, Tables 1 and 2 represent the main technological operations performed for EV diagnosing in the case of inspection and purchase and sale procedures, respectively. The tables also reflect the necessary resources.

Suppose there is a situational problem: an owner of an EV needs to carry out its inspection to sell it. At the service station, there are 4 mechanics, 2 masters, 1 specialist with a PC; there are 4 sections for diagnosing EV, and 6 units of technological equipment, which are designed for certain processes (see, for example, Tables 1 and 2). So, there are 6 different types of resources. We will also form an additional type of a resource, which consists of sets of diagnostic equipment that are used simultaneously during the provision of a comprehensive service, such as passing a roadworthiness test or assess-

ment of the technical condition of the EV in the case of selling it. Each of these resources has its working schedule for the next day.

Input data: working time 11 hours $\times 60$ minutes $=660 \mathrm{mi}-$ nutes; if you take the size of a time block as 15 minutes, the working time for each resource in time blocks is 44 blocks. The working day for all resources starts at 8 a.m. and ends at 7 p.m. Daily schedules for the next day for all 20 resources are presented below in the form of binary arrays (recall that " 0 " and " 1 " means open and reserved time blocks, respectively):

Type 1: Car mechanic

Resource 1: 11110000111111110000000011111111110000000000 Resource 2: 11111111111111110000001111111111111100000011 Resource 3: 00000000000000000000000000000000000011111110 Resource 4: 11111111111111110000000000000001111111111100

Type 2: PC specialist

Resource 5: 11000000011000000000000110000001100000000110

Type 3: Section for EV diagnosing

Resource 6: 00000000111100000000000000000000000000000000

Resource 7: 0011111111111111100011000111111111111000111100 Resource 8: 00001111111111110000000011111111110000000000 Resource 9: 11110000000000000000000011110000110000011000

\section{Type 4: Master}

Resource 10: 1111000011111111100000000111111111110000001000 Resource 11: 11111111111111111111111111111111111111111111

Type 5: Thickness gauge of a paint and varnish covering Resource 12: 11100000111111111111111111111111000000000010

Technological operations of diagnosing during technical inspection of an electric vehicle

\begin{tabular}{|c|c|c|c|c|}
\hline No. & The content of the technological operation & Material resources & $\begin{array}{l}\text { Duration, } \\
\text { min }\end{array}$ & $\begin{array}{l}\text { Specialists } \\
\text { involved }\end{array}$ \\
\hline 1. & $\begin{array}{l}\text { Organoleptic diagnosis of the vehicle and filling in the diagnostic card } \\
\text { of the technical inspection }\end{array}$ & Section for EV diagnosing, $\mathrm{PC}$ & 7 & $\begin{array}{l}\text { Master, } \\
\text { PC specialist }\end{array}$ \\
\hline 2. & $\begin{array}{l}\text { Mechanical validation of a steering knot, corners of driving wheels } \\
\text { installation }\end{array}$ & $\begin{array}{l}\text { Section for EV diagnosing, } \\
\text { stand for checking lateral } \\
\text { removal of wheels }\end{array}$ & 4 & Car mechanic \\
\hline 3. & Brake system check & $\begin{array}{l}\text { Section for EV diagnosing, } \\
\text { Power roller brake stand }\end{array}$ & 4 & Car mechanic \\
\hline 4. & Suspension system check & $\begin{array}{l}\text { Section for EV diagnosing, } \\
\text { Computer stand }\end{array}$ & 5 & Car mechanic \\
\hline 5. & Inspection of the low beam headlights, high beam headlights, fog lights & $\begin{array}{l}\text { Stand for checking and } \\
\text { adjusting the headlights }\end{array}$ & 5 & Car mechanic \\
\hline 6. & $\begin{array}{l}\text { Inspection of a technical condition by means of the computer scanner } \\
\text { of the main units, knots of the electric car: capacity of the storage } \\
\text { battery; functionality of the electric motor and the controller }\end{array}$ & $\begin{array}{l}\text { Car OBD scanner with wired } \\
\text { fittings, with the appropriate } \\
\text { software }\end{array}$ & 5 & $\begin{array}{l}\text { Master, } \\
\text { PC specialist }\end{array}$ \\
\hline Total & & & 30 & 3 \\
\hline
\end{tabular}

Table 2

Technological operations of diagnosing in the client request to carry out an assessment of a technical condition at purchase or sale of an EV

\begin{tabular}{|c|l|l|c|}
\hline No. & \multicolumn{1}{|c|}{ The content of the technological operation } & \multicolumn{1}{c|}{$\begin{array}{c}\text { Material resources } \\
\text { min }\end{array}$} & $\begin{array}{c}\text { Specialists } \\
\text { involved }\end{array}$ \\
\hline 1. & Organoleptic diagnosis of the vehicle & $\begin{array}{l}\text { Section for EV diagnosing, Thickness gauge of a } \\
\text { paint and varnish covering }\end{array}$ & $\begin{array}{l}\text { Car mechanic; } \\
\text { PC specialist }\end{array}$ \\
\hline 2. & $\begin{array}{l}\text { Mechanical validation of a steering knot, corners of } \\
\text { driving wheels installation }\end{array}$ & stand for checking lateral removal of wheels & 5 \\
\hline 3. & Brake system check & Power roller brake stand & 5 \\
\hline 4. & Suspension system check & Computer stand & Car mechanic \\
\hline 5. & $\begin{array}{l}\text { Checking the technical condition with a computer } \\
\text { scanner }\end{array}$ & $\begin{array}{l}\text { Car OBD scanner with wired fittings, with the } \\
\text { appropriate software }\end{array}$ & $\begin{array}{l}\text { Car mechanic } \\
\text { PC specialist }\end{array}$ \\
\hline Total & & & 25 \\
\hline
\end{tabular}


Type 6: Electrical equipment

Resource 13: 01110011111111100111111111111111110111111111 Resource 14: 00000000111100000000000000000000110000000000 Resource 15: 01110000000000000000000011110000110000010001 Resource 16: 00000011111111100000011111111111000000110000 Resource 17: 00000000111100000000000000000000110000000000

Type 7: Set of diagnostic equipment

Resource 18: 011100111111111001111111111111111110111111111 Resource 19: 11110000001111110000000011111000000000011000 Resource 20: 00000000111100001111000000000000110000100011

Table 2 shows that for one fast high-quality complete cycle of diagnostics when selling or buying an EV requires 2 car mechanics, a master, a specialist in PC, a site, a device for measuring the thickness of paint and varnish coating, and an OBD-scanner with wired fittings, with the appropriate software. Under acceptable conditions, the duration of diagnosis is 60 minutes ( 4 blocks of time) for each resource.

In such condition the input data of formulated model is as follows: $N=7, D_{1}=4, D_{2}=1, D_{3}=4, D_{4}=2 ; D_{5}=1, D_{6}=5$, $D_{7}=3 ; n=44 ; K=1 ; A_{1}=\{2,1,1,1,1,0,1\}-$ the required number of resources of the appropriate type; $\left[l_{1}, m_{1}\right]=[1$, $n]$ - the limits of the time interval during which you want to perform the corresponding service (if not set initially, it is assumed to be equal to the time interval of the daily schedule); $h_{1}=4-$ the number of consecutive time blocks provided by the service. Auxiliary data: the number of all possible combinations of resources that can provide the service: $Q_{1}=C_{4}^{2} C_{1}^{1} C_{4}^{1} C_{2}^{1} C_{1}^{1} C_{5}^{0} C_{3}^{1}=108$. Excluding from consideration those resources that do not have any gap of a size greater than or equal to $h_{1}$ in the schedule (in the example these are $R_{2}^{3}, R_{2}^{4}$, $R_{1}^{6}, R_{1}^{7}$ ), then $Q_{1}=C_{4}^{2} C_{1}^{1} C_{3}^{1} C_{1}^{1} C_{1}^{1} C_{4}^{0} C_{2}^{1}=4 \times 3 \times 2=24$, which is significantly less than the previous value.

Next, we add the vectors of resource participation in the "team" $T^{q}, q=1, \ldots, 24$. If all resources are written to a string, then the matrix $T$ will have a dimension $Q_{1} \times\left(D_{11}+D_{12}+D_{13}+\right.$ $\left.+D_{14}+D_{15}+D_{17}\right)=24 \times(4+1+3+1+1+2)$. Here $D_{1 i}$ indicates the number of $i^{\text {th }}$ resources that have at least one gap of the desired size.

Thus, a certain composition of the "command" will correspond to each row of the matrix $T$

\begin{tabular}{|c|c|c|c|c|c|c|c|c|c|c|c|c|}
\hline No & $\left|R_{1}^{1}\right|$ & $R_{2}^{1}$ & $R_{3}^{1}$ & $R_{4}^{1} \mid$ & $R_{1}^{2}$ & $R_{1}^{3} \mid$ & $R_{3}^{3} \mid$ & $R_{4}^{3} \mid$ & $R_{1}^{4}$ & $R_{1}^{5}$ & $R_{2}^{7} \mid$ & $R_{3}^{7}$ \\
\hline 1 & 1 & 1 & 0 & 0 & 1 & 1 & 0 & 0 & 1 & 1 & 1 & 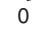 \\
\hline 2 & 1 & 1 & 0 & 0 & 1 & 1 & 0 & 0 & 1 & 1 & 0 & 1 \\
\hline 3 & 1 & 1 & 0 & 0 & 1 & 0 & 1 & 0 & 1 & 1 & 1 & 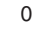 \\
\hline 24 & 0 & 0 & 1 & 1 & 1 & 0 & 0 & 1 & 1 & 1 & 0 & \\
\hline
\end{tabular}

For each resource selection option $T^{q}, q=1, \ldots, 24$ compose vector $S^{q}$

\section{$S^{1}=11110000111111110000000011111111110000000000$ 1111111111111111100000011111111111111100000011 11000000011000000000000110000001100000000110 00000000111100000000000000000000000000000000 11110000111111110000000011111111110000001000 11100000111111111111111111111111000000000010 11110000001111110000000011111000000000011000 111111111111111111111111111111111111100011111 \\ $S^{2}=11110000111111110000000011111111110000000000$ 00000000000000000000000000000000000011111110

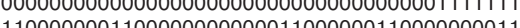

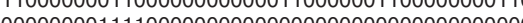 00000000111100000000000000000000000000000000 111100001111111100000000111111111110000001000 11100000111111111111111111111111000000000010 11110000001111110000000011111000000000011000 11110000111111111111111111111111110011111110 \\ $S^{24}=0000000000000000000000000000000000011111110$ 111111111111111110000000000000001111111111100 1100000001100000000000110000001100000000110 11110000000000000000011110000110000011000 11110000000000000000011110000110000011000 11110000111111110000000011111111110000001000 111000001111111111111111111111111000000000010 $\underline{00000000111100001111000000000000110000100011}$ 11111111111111111111111111111111111100011111}

It is easy to notice, that $f^{1}=\varnothing, f^{24}=\varnothing$, and, for instance, $f^{*}=\{4\}$. Going through all the input elements of the arrays $f^{1}, \ldots, f^{24}$, we find the smallest one. It will indicate the block number, starting from which the section can provide the service. The index $x$ of the array $f^{x}$, to which the found number belongs, determines the composition of the team, i.e. the resources of the service station that must be used during the service. If there are several such indexes, you can get all the teams (to be able to select the team by the client) or enter a quality criterion (such as the minimum total size of gaps in the schedule of a particular resource). Therefore, in this example, the nearest service time is 9.00 , and the resources that will be involved are as follows: $R_{1}^{1}, R_{3}^{1}, R_{1}^{2}, R_{1}^{3}, R_{1}^{4}, R_{1}^{5}, R_{3}^{7}$.

Discussion. The satisfaction of EV clients' requirements is carried out due to the organization of a diagnostic service that is based on the usage of modern technologies and technological equipment, the availability of highly-qualified personnel, and the breadth of the range of services. When accidentally loading EV diagnostic sites in the flow of applications for their implementation, condensation and rarefaction, as well as uneven loading of technological equipment take place. It leads either to a denial of the service or to the formation of a queue. The peculiarity of the proposed approach to solving the problem of reservoir resource reservation is the software implementation of the mathematical model. Firstly, the software will constantly monitor the occupancy of resources and take into account unforeseen events (for example, customer failure). Secondly, it will create such a working schedule that will increase its capacity.

The specificity of the presented model, which distinguishes it from existing models of scheduling theory problems, is the ability to solve a problem with several different optimality criteria simultaneously and provide all possible options for customer service discretion for further choice. This way of interaction between the client and the service company has a positive effect on the company's reputation and, in turn, can increase the flow of service requests.

\section{Conclusion.}

1. The analysis of the technological processes of diagnosing EV is carried out. The information on the main services provided by EV SS is collected and systematized. For each service, it is established what processes make it, how many resources are involved, the duration of each operation is calculated.

2. The mathematical model on the organization of work of EV SS with the rational distribution of its resources, which has appeared to be constructive and reproduces the process of solving the problem, is constructed. The application of the proposed approach is demonstrated on the model problem of optimal resource reservation for the provision of the next service under conditions of limited resources.

3. The expediency of using the developed tools to ensure the effective operation of the EV SS, which increases due to reducing the downtime of equipment or human resources, as well as meeting the needs of all customers who approached the company, is explained.

4. The proposed mathematical model is generalized so that it can be used in any service company that seeks to rationally allocate its resources when providing services to a large number of customers.

References.

1. Hertzke, P., Müller, N., Schaufuss, P., Schenk, S., \& Wu, T. (2019). Expanding Electric-Vehicle Adoption despite Early Growing Pains. McKinsey \& Company. Retrieved from https://www.mckinsey.com/industries/automotive-and-assembly/our-insights/expanding-electric-vehicle-adoptiondespite-early-growing-pains.

2. Jin, L., \& Slowik, P. (2017). Literature review of electric vehicle consumer awareness and outreach activities. International council on clean transportation. Retrieved from https://theicct.org/sites/default/files/publications/Consumer-EVAwareness_ICCT_Working-Paper_23032017_vF.pdf. 
3. Koriashkina, L. S., Deryugin, O. V., Fedoriachenko, S. O., Cheberiachko, S. I., \& Vesela, M.A. (2019). On determining productive capacity of EV traction battery repair area. Naukovyi Visnyk Natsionalnoho Hirnychoho Universytetu, (5), 113121. https://doi.org/10.29202/nvngu/2019-5/17.

4. Auto 24 (2019). The most common causes of road accidents in Ukraine in 2019 are named. Retrieved from https://https:// auto.24tv.ua/nazvano naiposhyrenishi_prychyny_dtp_v ukraini_v_2019_rotsi_n17019.

5. Sabraliev, N., Abzhapbarova, A., Nugymanova, G., Taran, I., \& Zhanbirov, Zh. (2019). Modern aspects of modeling of transport routes in Kazakhstan. News of the National Academy of sciences of the Republic Kazakhstan. Series of Geology and technical sciences, 2(434), 62-68. https://doi.org/10.32014/2019.2518170X.39.

6. Sładkowski, A., Utegenova, A., Kolga, A.D., Gavrishev, S.E., Stolpovskikh, I., \& Taran, I. (2019). Improving the efficiency of using dump trucks under conditions of career at open mining works. Naukovyi Visnyk Natsionalnoho Hirnychoho Universytetu, (2), 36-42. https://doi.org/10.29202/ nvngu/2019-2/8.

7. Taran, I.A., \& Klymenko, I.Y. (2014). Innovative mathematical tools for benchmarking transmissions of transport vehicles. Naukovyi Visnyk Natsionalnoho Hirnychoho Universytetu, (3), 76-81.

8. Hu, J., Morais, H., Sousa, T., \& Lind, M. (2016). Electric vehicle fleet management in smart grids: A review of services, optimization and control aspects. Renewable and Sustainable Energy Reviews, 56, 1207-122. https://doi.org/10.1016/j. rser.2015.12.014.

9. Yan, Q., Zhang, B., \& Kezunovic, M. (2019). Optimized Operational Cost Reduction for an EV Charging Station Integrated With Battery Energy Storage and PV Generation. IEEE Transactions on Smart Grid, 10(2), 2096-2106. https://doi. org/10.1109/TSG.2017.2788440.

10. Erdelić, T., \& Carić, T. (2019). A Survey on the Electric Vehicle Routing Problem: Variants and Solution Approaches. Journal of Advanced Transportation, 2019, 1-48. https://doi. org/10.1155/2019/5075671.

11. Voloshin, D., \& Afanasenko, I. (2019). Assessment of the efficiency of functioning of wagon repair enterprises. Transportation systems and technologies, 1(33), 78-85. https://doi. org/10.32703/2617-9040-2019-33-1-7.

12. Sheng, K. J., Baharudin, A.S., \& Karkonasasi, K. (2016). A Car Breakdown Service Station Locator System. International Journal of Applied Engineering Research, 11(22), 11037-11040. 13. Adekunle, A. A., Ikubanni, P., \& Olayinka, A. (2018). An Expert System for Automobile Repairs and Maintenance. Mindanao Journal of Science and Technology, 16(1), 41-56.

14. Averchenkov, V. I., Yakimov, A. I., Yakimov, E. A., \& Ivkina, N. N. (2016). Optimization problem of control by simulation model formation in corporate information system. Bulletin of Bryansk State Technical University, 2(50), 207-214. https://doi.org/10.12737/20291.

15. Bolino, M.C., Kelemen, T. K., \& Matthews, S. H. (2019). Working 9-to-5? A Review of Research on Nonstandard Work Schedules. Journal of Organizational Behavior, https://doi. org/10.1002/job. 2440 .

16. De Jonge, B., \& Scarf, P. (2019). A review on maintenance optimization. European Journal of Operational Research, 285(3), 805-824. https://doi.org/10.1016/i.ejor.2019.09.047.

17. Tilley, S. (2019). System Analysis and Design. CENGAGE Learning Custom Publishing. ISBN-13: 978-0357117811.

18. Koriashkina, L. S., \& Belyaev, O. R. (2019). Determination of the optimal number and location of charging stations for electric vehicles in the city. Computer Modeling: Analysis, Control, Optimization, 1, 23-29. https://doi.org/10.32434/25216406-2019-5-1-23-29.

19. Pinedo, M. L. (2016). Scheduling: Theory, Algorithms and Systems ( $5^{\text {th }}$ ed.). Berlin: Springer. https://doi.org/10.1007/9783-319-26580-31.
20. Georgiadis, G., Elekidis, A.P., \& Georgiadis, M.C. (2019). Optimization-Based Scheduling for the Process Industries: From Theory to Real-Life Industrial Applications. Processes, 7(7), 438. https://doi.org/10.3390/pr7070438.

\section{Раціональна організація роботи станції технічного обслуговування електромобілів}

\section{С. І. Чеберячко, Л. С. Коряшкіна, О. В. Дерюгін, М.М. Одновол}

Національний технічний університет «Дніпровська політехніка», м. Дніпро, Україна, e-mail: koriashkina.1.s@ $\underline{\text { nmu.one }}$

Мета. Підвищення ефективності роботи станції технічного обслуговування (СТО) електромобілів (ЕМ) за рахунок раціонального розподілу ії ресурсів.

Методика. Системний аналіз технологічних процесів діагностування ЕМ в залежності від потреб клієнта; математичне моделювання, дослідження операцій, комбінаторна оптимізація.

Результати. Проведено аналіз технологічних процесів діагностування ЕМ. Зібрана й систематизована інформація щодо основних послуг, що надає СТО ЕМ. Для кожної з них встановлено, які процеси складають послугу, їх ресурси, в якій кількості при цьому вони задіяні, а також тривалість кожної операції. Побудовані математичні моделі з організації роботи СТО ЕМ, що дозволяють забезпечити рівномірне завантаження наявних ресурсів і визначати найближчий час надання чергової послуги. Вирішена модельна задача щодо резервування ресурсів задля обслуговування більшого числа клієнтів. Запропонована математична модель носить узагальнений характер, оскільки іiї можна використовувати на будь-якому підприємстві сфери обслуговування, яке прагне раціонально розподіляти свої ресурси під час надання послуг якомога більшій кількості клієнтів.

Наукова новизна. Встановлено, що ефективність роботи СТО ЕМ збільшується за рахунок зменшення часу простою обладнання або людських ресурсів, а також обслуговування якнайбільшої кількості клієнтів, що звернулися до сервісного підприємства.

Практична значимість. Запропонована математична модель, що дозволить, по-перше, відслідковувати зайнятість ресурсів підприємства; по-друге, забезпечить збільшення пропускної спроможності за рахунок раціонального використання ресурсів.

Ключові слова: електромобіль, станція технічного обслуговування, процес діагностування, комбінаторна оптимізація

\section{Рациональная организация работы станции технического обслуживания электромобилей}

\section{С. И. Чеберячко, Л. С. Коряшкина, О. В. Дерюгин, Н. Н.Одновол}

Национальный технический университет «Днепровская политехника», г. Днепр, Украина, e-mail: koriashkina.1.s@ nmu.one

Цель. Повышение эффективности организации работы станции технического обслуживания (СТО) электромобилей (ЭМ) за счет рационального распределения её ресурсов.

Методика. Системный анализ технологических процессов диагностирования ЭМ в зависимости от потребностей клиента; математическое моделирование, исследование операций, комбинаторная оптимизация. 
Результаты. Проведен анализ технологических процессов диагностирования ЭМ. Собрана и систематизирована информация об основных услугах, предоставляемых СТО ЭМ. Для каждой из них установлено, какие процессы составляют услугу, их ресурсы, в каком количестве при этом они задействованы, а также длительность каждой операции. Построены математические модели по организации работы СТО ЭМ, которые позволяют обеспечить равномерную загрузку имеющихся ресурсов и определять ближайшее время предоставления очередной услуги. Решена модельная задача по резервированию ресурсов для обслуживания как можно большего числа клиентов. Предложенная математическая модель носит обобщенный характер, поскольку ее можно использовать на любом предприятии сферы обслуживания, которое стремится рационально распределять свои ресурсы при предоставлении услуг большому количеству клиентов.
Научная новизна. Установлено, что эффективность работы СТО ЭМ увеличивается за счет уменьшения времени простоя оборудования или человеческих ресурсов, а также обслуживания как можно большего количества клиентов, обратившихся на сервисное предприятие.

Практическая значимость. Предложена математическая модель, которая позволит, во-первых, отслеживать занятость ресурсов предприятия; во-вторых, обеспечить увеличение пропускной способности за счет рационального использования ресурсов.

Ключевые слова: электромобиль, станиия технического обслуживания, процесс диагностирования, комбинаторная оптимизация

Recommended for publication by V.V.Sliesariev, Doctor of Technical Sciences. The manuscript was submitted 12.03.20. 